\title{
Consensus
}

Volume 15

Issue 1 Mission of the Church

Article 17

5-1-1989

\section{The intellectual origins of the European Reformation}

Timothy R. Cooke

Follow this and additional works at: http://scholars.wlu.ca/consensus

\section{Recommended Citation}

Cooke, Timothy R. (1989) "The intellectual origins of the European Reformation," Consensus: Vol. 15 : Iss. 1 , Article 17. Available at: http://scholars.wlu.ca/consensus/vol15/iss1/17

This Book Reviews is brought to you for free and open access by Scholars Commons @ Laurier. It has been accepted for inclusion in Consensus by an authorized editor of Scholars Commons@ Laurier. For more information, please contact scholarscommons@wlu.ca. 
concern, the same church which had now existed for 15 centuries. If the main concern of the Reformation were not the protest of the church, and thus also of the gospel, against the errors of the papacy and its abuses of power, then it would be nothing but an unfortunate mistake. The merits of this position will not be discussed here, but it must be noted that, no matter how many modifications are deemed necessary, the basic viewpoint of the $\mathrm{AC}$ is the only tenable one for any adherence to the reformers' confession. If one accepts these conditions, one must draw the necessary consequences. The cause of the Reformation must not be allowed to be reduced to confessionalism (210).

Do the Lutheran confessions remain for us the protest of the Gospel against ecclesiastical abuses or have we reduced ourselves to mere confessionalism?

Robert A. Kelly

Waterloo Lutheran Seminary

The Intellectual Origins of the European Reformation Alister McGrath

Oxford: Basil Blackwell, 1987 203 pp., $\$ 68.95$

In this expensive volume Alister McGrath has undertaken to unravel the historiographical web which entangles the intellectual origins of the Reformation. McGrath's particular emphasis is the impact of the scholastic and humanist movements on the nascent ideas of the Reformers. A daunting enormity of an emphasis, to be sure, but McGrath's chosen task is the big picture, la longue durée of intellectual mutation. The epic proportions aside, the book is a survey of pertinent issues and a reflective summation of the debate.

McGrath's analysis is organized around four broad themes: the medieval precedents of the Reformation; the relationship between the Renaissance and the Reformation; the influence of late medieval theology upon the Reformation; and the apparent anomaly of Reformation scholasticism. Given these foci, McGrath's reading of the issues is one which seeks to establish similarities and homologies between the Reformation and the intellectual climate of the late middle ages. McGrath insists that there is a continuity of humanist and Reformation textual interests, shared in the quest ad fontes. The discontinuity emerges in hermeneutical principles employed, that is to say, the Reformation concern to encounter and apply in Scripture the living Word of God. Within the Reformation McGrath traces different pedigree lines to the Lutheran and Reformed traditions. 
The Reformed tradition is depicted as the special inheritor of the Renaissance whereas Luther's theological breakthrough is interpreted as a special effusion within the late medieval spiritual tradition. In other words, the Reformed exegetical principle of scriptura sui ipsius interpres and the scholasticism which inevitably accompanied it is attributed to the humanist roots of Calvin and Zwingli. This leads McGrath to a series of unremarkable conclusions, such as:

The quest for the intellectual origins of the Reformation thus concerns not the identification of a single factor, nor even a group of factors, which may be said to have caused the movement, but rather concerns the unfolding of a complex matrix of creatively interacting intellectual concerns, whose precise mode of interaction was determined as much by local as by cosmopolitan, by social as by academic, factors (197-198).

These and other truisms blunt the edge of Occam's razor. McGrath's flare for finely textured argument and his erudition is ill-served in this overview of gargantuan historical-ideological problems. Lurking behind McGrath's able unpacking of vexatious historiographical points of contention is a monolithic understanding of the larger intellectual processes. There is, for instance, no mention of the Reformation radicals who alternately tantalize or bedevil similar analyses. McGrath's somewhat rigid and narrowly intellectual approach to the subject matter did not result in a compelling new interpretation of the origins of the Reformation. Instead, the prospective reader can await expert direction along some well trodden paths of Reformation research.

Timothy R. Cooke

St. Peter's Anglican Church, Brockville, Ontario

Faith, Reason and Theology: Questions I-IV of his Commentary on the "De Trinitate" of Boethius Thomas Aquinas

Translated by Armand Maurer

Toronto: Pontifical Institute of Medieval Studies, 1987 [Medieval Sources in Translation, 32] 110 pp. $\$ 6.50$

One of the many common opinions clung to by Christians today insists that we can simplistically divide individuals into "head" and "heart". The "head", according to this pattern of thought, includes everything associated with reason, the intellect, systematisation in theology, and ivory-tower theory, and is depicted as negative; the "heart", on the other hand denotes the realm of faith, the feelings, intuitive insight, "praxis", the good.

This commonplace is unfortunately pervasive, and not only does it continue to misinform Christians in every vocation, but it shares along with 